\title{
A Reflection on Parents' Responsibility for Harmful Acts of Major, Foolish and Physically Disabled Children in the Islamic Jurisprudence and Iranian Law
}

\author{
Siroos Heidari ${ }^{1}$, Amir Ali Khodaie ${ }^{2}$ \& Davood Janbazi ${ }^{2}$ \\ ${ }^{1}$ Assistant Professor of Private Law, Shiraz University, Shiraz, Iran \\ ${ }^{2}$ M.A in Private Law, Qom University, Iran \\ Correspondence: Siroos Heidari, Assistant Professor of Private Law, Shiraz University, Shiraz, Iran. E-mail: \\ heidaris@shirazu.ac.ir
}

Received: May 31, 2017

doi:10.5539/jpl.v10n4p146

\begin{abstract}
In this research, we seek to talk about civil responsibility of parents for acts of their children with juridical and legal approach. The main problem is that whether the parents have civil responsibility for harmful acts of their major and foolish children or not. The parents have civil responsibility for harmful acts of their foolish children (minor or mature) until they have custody on them. In the opinion of most of Islamic jurists, the parents' right and duty of custody on their children will be expired by majority and mental maturity of the child. In addition, the parents will be liable for damages derived from the acts of their minor or insane children until they have protection and supervision duty on them. In all of the cases, failure to take care of the incapable person constitutes the legal basis of the parents' liability. It may be said that the parents have responsibility for any losses arising from their failure to protect and take care of their physical disable children.
\end{abstract}

Keywords: civil responsibility, parents, children, foolish, lunatic, disabled person

\section{Introduction}

Usually and principally, each person is responsible for the consequences and effects of his/her harmful acts and the law obliges the persons to do their duties and prevent from doing some acts; whenever they didn't act in such manner and a harm occurred, they have to compensate it. But, law sometimes knows the persons responsible for act of another and in fact due to the loss which has been caused by another person. This is sometimes due to the legislator's support from harmed person and sometimes due to the support from the person under supervision, like civil responsibility of parents for children and children's responsibility for parents. Generally, the responsibilities of parents and children for each other are two kinds: The responsibility arising from personal act; namely, a harm that parents as their supervisor exert on them in the period of taking care of children or a harm that the children exert on their parents in the period of taking care of them. The second kind of responsibility of parents and children for each other is the responsibility arising from another one's act (Vicarious Liability); namely, the responsibility of parents for the harms exerted on harmed person on behalf of children under their protection or a responsibility that children have for the losses arising from the acts of parents under their supervision and protection. It should be noted that the purpose of parents' responsibility for child isn't this issue that they are responsible for the harms that exert on each other; rather, the purpose of our discussion is the second kind of parents' responsibility. In other words, whether the parents have civil responsibility for the losses that child exerts on others or child has civil responsibility for the harms that the parents exert on others.

\section{The Parents' Responsibility for Harmful Acts of Major and Foolish Children}

Before expressing this issue that whether the parents have civil responsibility for major children or not, at first, it is better that the growth age (mental maturity) and majority to be discussed briefly. The concept of majority is used vs. minority and minor according to the first Civil Code was said to a person who hadn't reached to the age of full 18 years (Emami, 2011, P.206). The law assumed that the mental powers of a person who hasn't reached to the full 18 years, haven't grown sufficiently and this person can not manage his/her affairs independently. Article 1209 of Civil Code in expressing this point stipulated: «Anyone who isn't full eighteen years old is non-mature (Imbecile/foolish) person. Nevertheless, in the event that after full 15 years, mental maturity of a 
person is proved before the court, he/she will exit from being under guardianship». In amendment of Civil Code in 1982, this article was eliminated by judicial commission of parliament and this elimination was approved by parliament at 1992. In addition, amendment of article 1210 of Civil Code in a manner that the judicial commission had approved in 1982 was approved by parliament (Safai, 2007, P.81). In the amended law, the age of 18 years is not considered as presumption of majority. According to the note 1 of amended article 1210 of Civil Code: «The age of maturity in boy is full 15 lunar years and in girl, it is full nine lunar years». According to the interpretation of the supreme court of article 1210 of Civil Code, for exiting from protection in financial affairs, reaching to the maturity age isn't sufficient, rather in addition to the legal maturity, mental maturity is also necessary and in the event that mental maturity of a person is confirmed, he/she may have financial independency and possess his/her properties independently. This interpretation conforms to the Imamate jurisprudence (Safai, 2007, P.81) while it isn't compatible with the appearance of amended article 1210. The Civil Code hasn't mentioned the competent authority for cognition of growth (mental maturity) and principally, the competent authority in this regard will be the court. Nevertheless, since referring to the court in any case causes severe difficulty, the courts, administrations, formal documents offices, banks and other persons consider practically the age of 18 years as the growth presumption and they consider a person who has reached to the full solar 18 years as a mental mature one with competence of possession, unless lack of growth of him/her or his/her insanity has been proved in the court. In confirming and justifying this procedure, the Act Relates to Growth (Mental Maturity) of Contracting Parties approved in 1934 has been sometimes resorted; while referring to that act, despite of elimination of the age of 18 years in Civil Code, is objectionable. It can be mentioned that the existing procedure has been adopted with regard to the society's needs and necessity of determination of special age as the growth (mental maturity) presumption and in order to resolve the practical problems of the people. This procedure indicates the resistance of lawyers, judges and formal authorities against careless decision of legislator in elimination of the age of 18 years as the growth presumption and the best solution is to amend the Civil Code and revive the former articles 1209 and 1210 of Civil Code based on acceptance of intended age as the growth (mental maturity) presumption (Safai \& Qasemzadeh, 2007, P.221).

In France's law, according to the article 388 of Civil Code: «Minor is a person who hasn't reached to the full 18 years»; therefore, until a time that child reaches to the majority age, the assumption mentioned in the clause 4 of article 1384 is applied against the parents; because from the conditions of execution of clause 4 of article 1384 (the assumption of parents' fault) is that the parents should undertake the parental custody and consequently, they should be obliged to take care of minor who exerts the harm. Minor in France's law (since 1974) is a person who hasn't reached to the full 18 years, while in Switzerland; the majority age is still 20 years. Whenever, the minor has been cognized as mature and exited from protection -which is only possible after reaching to the age of full 16 years- the assumption of parents' fault will not be run. Of course, according to the general rules of civil responsibility, the harmed person can prove that the parents have committed a personal fault by giving non-opportune and early independency to their child (article 428 of amended Civil Code, $14^{\text {th }}$ December, 1964). In France's law, removal of incapacity (except in some cases) gives to a minor the possibility of governing on himself, profiting from properties and managing them (Doroudian, 1997, P.34). Removal of incapacity may be by marriage; each minor who marries, merely and automatically exits from protection without any need to any announcement (article 476 of French Civil Code). Also, removal of incapacity may be accomplished by the decision of guardianship affairs judge. In this state, the request of parents or one of them and in the state of lack of them, the demand of family council with presentation of acceptable reasons and motivations is necessary (articles 476-477 of Civil Code). Anyway, as it was mentioned, the minor should have reached to the age of full 16 years old to be able to exit from protection.

According to the article 481 of Civil Code of France, a minor who has exited from being under protection, like a major person, has the competence for doing all acts of civil life. In Egypt's law, minor is a person who hasn't reached to the age of 21 years old. But, any minor doesn't need to be protected (taken care), a minor that taking care of him/her is necessary will be one of these two persons: A person who hasn't reached to the age of 15 years old and a person who has reached to the mentioned age but he/she is still under the protection and nurture of another one. Taking care of minor below 15 years old is necessary and his/her protector is responsible for illegitimate acts of the minor. Habitually, child in this age has common residing with a protector like father, fatherhood grandfather, uncle or mother. But, a minor who has reaches to the age of 15 years old, doesn't need to be protected unless he/she is under nurture of another one and depends on him/her for livelihood (Hejazi, 1954, PP.520-521). In America's law, the age of 21 years old was cognized as the maturity age; but the maturity age was reduced to the age of 18 years old at 1970 (Nazari, 2009, P.6). 


\subsection{Civil Responsibility of Parents for Harmful Acts of Major Children}

Before entering to the discussion, this point is necessary to be reminded that the responsibility predicted in the article 7 of Civil Liability Law is arising from the duty related to take care of incapable not having relationship. So, it should be seen that whether there is any duty of protection (custody) or not.

In Iran's law, the amended article 1169 of Civil Code approved in 2003 stipulates: «For protecting and taking care of a child that his/her parents live separately, mother has priority until the age of 7 years old and after it, this duty is undertaken by the father» and article 1168 of the same code stipulates: «Taking care of child is both right and duty of parents». However, it hasn't expressed any sentence about this issue that when the duty of parents is finished. In responding to this question, it should be said that although son or daughter till any age is so-called "child", but based on what is inferred from articles 1168-1169 of Civil Code, only the responsibility of a son or daughter that is minor will be undertaken by parents. Civil Code of Iran hasn't defined minor and but with regard to the provisions related to the protection and supervision specially articles 1207 and 1210 of Civil Code, minor is said to a person who has not reached to the maturity age and minority is placed versus maturity (majority). According to the note of article 49 of Islamic Penal Code: «The purpose of minor is a person who hasn't reached to the extent of religious maturity». But, what is the religious maturity? In Iran's law, according to the article 1210 of Civil Code, daughter is accounted mature after reaching to the full lunar 9 years and son is accounted mature after reaching to the full lunar 15 years and they aren't considered as minor after reaching to the intended age. Thus, with reaching to the mentioned ages, the duty of protection (custody) is invalidated principally and its duration will be expired (Safai \& Emami, 2006, p. 346).

Also, by referring to the opposite concept of article 7 of Civil Responsibility Law, it may be claimed that the duty of protection by parents (custody) is related to the minor children not major ones. Of course, perhaps by adducing to the article 1177 of Civil Code that has stipulated: «The child should obey from his/her parents and respect to them at any age», some persons claim that from stipulation of «at any age» and historical record of article 1177 (article 377 of Civil Code of France and Islamic instructions related to the necessity of respecting to the parents), it is clarified well that the purpose of legislator isn't minor, his purpose is the child either minor or major (Katouzian, 1993, p.135). However, in responding to this claim, it should be said that sentence of the article 1177 of Civil Code rather has ethical aspect. Therefore, despite of this fact that Civil Code doesn't have any sentence about it, from applying the word of «minor» in the legal articles, it is understood that principally the duty of parents ends with majority of child (Katouzian, 1993, p.151) and thereupon, they aren't responsible for his/her harmful acts. But, is there any exception to this rule or don't custom give flexibility to this rule? It should be said that each juvenile after reaching to the maturity age and before entering to the society still needs to be protected. Due to this, in the meantime that the right and duty of protection are invalidated, practically, ethically and in terms of individual and social expedient, the parents know themselves obliged to continue their protection and control on the child till a time that child reaches to the stage of practical independency and this control on daughter principally is continued till marriage and formation of family; but on the son it usually ends after being employed in an occupation.

Due to this, restricting the duration of custody to the mentioned age is contrary to the religious law and expedients and it may be criticized (Safai \& Emami, 2006, P.346). For example, we assume that a son is passing the last years of high school in an age close to 15 years old and wishes to go to the university. In this time, he reaches to the growth age and exits from the father guardianship. He has the ability to work and if father doesn't have special duty in nurturing him in terms of rules related to the relatives' maintenance (article 1197 of Civil Code). Thus, we can not force him to pay the expenses of life and education of the child. But, is it in such manner the approach of ethics and custom? Another example: A daughter after maturity is at the beginning of learning the skills of reading and writing or stays at home and waits for finding a proper occupation or husband. In such sensitive and critical period, can father abstain from protection of her and send her out of the home under the excuse of this issue that the daughter has the ability to work? Whether it may be accepted that such a father has done his legal and social duty in nurturing, protecting from child, bringing up the child and delivering her to the society or not? For these reasons, some of sociologists have expressed their worry and regret about this issue that with reaching to the majority age, the duties related to protect from child are cut suddenly and now in France, a new tendency has been created that some of duties of parents (specially providing the expenses of education of child that has begun it in childhood) remain till a duration of growth (mental maturity) age (Katouzian, 1993, p.152). Specially, at current law which the maturity age of daughter is on the verge of her discernment period, a period in which child is usually schooling, how can we deprive such juvenile from family support or force her to pay her life expenses?

Law is fostered in the shadow of justice and ethics and reaches to the perfection and don't accept such injustice. 
Furthermore, can a government which «to create the favorable fields for growth of woman's personality and revive her material and moral rights» is one of its duties (clause 1 of principle 21 of Constitution), support from such a rule? So, it can be said, since law doesn't have any explicit sentence about the date of the end of protection period, judge should respect to the soul of law (supporting the juveniles and providing healthy and efficient human force for society) and the usage in such cases (article 30 of Civil Procedure Code) and in any case that the period of transmitting the child from family to the society needs the continuation of parents' duties, he shouldn't hesitate in identifying and guaranteeing it, whether like France's law it is a little after the growth age or more. In addition, about a daughter that hasn't married yet, the father's option in permitting or rejecting her marriage may be considered as a field for the sentence on the permanence of mutual duty of this option. Clause 3 of article 58 of Social Security Law, approved in July 1975, according to the same thought, accounts the insured children who are schooling according to the testimony of one of the formal educational institutes and daughters till 20 years old on the condition of not having husband as the members of insured family; namely, it assumes that livelihood of this kind of children is still undertaken by parents (note 1 of article 72 of the same law). The existence of this assumption may be an evident reason for permanence of parents' duty in the mentioned cases.

The maturity criterion as a standard for expiry date of protection (custody) also has some believes among Sunni jurists. Some believes that the duration of protection is different in son and daughter; namely, the extreme duration of protecting from male children is till a time that they reach to the maturity age, while daughter remains under the mother protection till a time that hasn't married (Jaziri, 1986, pp.598-599). Some other Sunni jurists believe that protection ends with discernment and before maturity (Ahmad ben Hamzeh, 1984, P.335). A group of jurists believe that protection (custody) doesn't end with reaching to the maturity age (Najafi, 1987, P.301; Al-Āmeli, 2007, p.332, Tabatabaee, 2000, p.254). Saheb Jawaher says: «There is no dispute in this issue that whenever the minor reaches to the majority and growth (mental maturity) age, the parents' guardianship on him/her is invalidated» (Najafi, 1987, p. 301). This problem has been proposed about custody and custody is accounted a kind of guardianship. Furthermore, the parents' custody has been discussed in the above phrase. Thus, it should be said that hereon the purpose of guardianship is the same custody. After the end of custody by maturity and growth, daughter and son have option to live with each one father and mother (each one that they want) (Al-Āmeli, 1995, p.426). But, it is recommended that the child not to be separated from his/her mother, especially daughter till a time that marries. The reason for termination of custody with maturity and growth is this issue that custody is guardianship and no one has guardianship on mature person (Al-Āmeli, 1995, p.426). In addition, guardianship is contrary to the principle. Also, $6^{\text {th }}$ blessed verse of Nesa Surah is a reason for it (Motahhari, 1984, p.544). According to this idea -on which the consensus has been claimed- custody doesn't end merely because of reaching to the maturity age, rather for invalidation of custody, realization of growth (mental maturity) is also necessary and till a time that the growth (mental maturity) of person hasn't been confirmed, the parents or another one's protection is continued and in the event that the parents commit a fault in this regard, according to the article 7 of Civil Responsibility Law, they will be responsible for compensation of incurred losses. Although this idea with consideration to the low age of maturity and today's social conditions seems more proper, but with regard to this issue that growth (mental maturity) is related to the financial affairs in the civil jurisprudence and law and protection from child is a non-financial affair, it may be criticized. Perhaps due to this, some of contemporary jurists have remarked that the duration of custody ends when child reaches to the maturity age (9 years old in daughter and 15 years old in son) and after it, child selects each one of the parents for living (each one that he/she wants) and this view has been attributed to the Shia jurists (Moqniyyah, 1995, p.379).

The proposed objection is correct in non-financial affairs where there is no control on foolish one; but in the financial affairs where there is control on them, the continuation of father custody and his control on the financial affairs of foolish one till his mental maturity may be justified and if foolish one transacts with another one, since only father has control on his/her financial affairs, he will be responsible in the event of committing any fault in protection. Of course, on the condition that the injured party has been ignorant of his imbecility. In Egypt's law, according to the clause 2 of article 173 of Civil Code, minor till reaching to the age of 15 years old which is accounted the age of autoerotism in Islam religion, is known absolutely as a person who needs to be protected. Usually, minor till the mentioned age is under the support of a person who undertakes nurture of him/her. But, with reaching to 15 years old and exiting from the nurture bonds and not living in the shelter of another one's support and earning independent revenue, no one will be responsible for his/her acts no more. If the child after reaching to 15 years old is still living under the support of another one that undertakes the nurture of him/her, he is accounted as the legal protector of child. These persons remain responsible for acts of the child till a time that child reaches to the growth age and his/her independent life begins. Of course, the purpose of independency in life hereon isn't to have independent house; because, perhaps a child lives with his/her father in one house but in subsistence affair is accounted independent from the father and father doesn't have any control 
on his/her nurture. Consequently, he isn't responsible for acts of the child; or sometimes the father and child live in a common house but father has been still controlling on nurture of his child and is cognized responsible for his/her acts. So, it is clarified that minor till the age of 15 years old should be under the supervision of a person who is responsible for minor's acts. When child reaches to the age of 15 years old but he/she is still under the support of a person who undertakes his/her nurture, that person is responsible for child's acts till a time that child begins an independent life or reaches to the growth (mental maturity) age (Dadmarzi \& Danesh Kia, 2009, P.204). In our belief, the legislator has been never in the position of expressing the end of custody in the article 1168 of Civil Code, but only he has wanted to express the positive aspect of custody. Although, this idea doesn't remove the fault on law, but we will be released from the corrupted consequent that may be gained by conceptualization of above article which consists of this issue that: «When child reaches to the maturity age, custody also ends». Therefore, till removing the legal defect in this field, according to the principle 167 of Constitution, tribunals are obliged to issue their judgments according to the valid Islamic resources. The most of Islamic jurists believe that the child exits from custody in the event that he/she becomes physically and mentally mature (Najafi, 1987, p.301). After reaching to the majority and mental maturity age, the child has option to be beside parents or others (Najafi, 1987, p.301) and in the event that he/she is beside the parents and they have control on him/her, they will be responsible in the event of fault.

\subsection{Civil Responsibility of Parents for Harmful Acts of Foolish Children}

Whether we believe that custody ends by majority or majority and growth (mental maturity), the mother doesn't have any control on financial affairs of the child and only the father has control on theses affairs. Thus, the protection by mother is related to non-financial affairs. In confirming this idea, we can refer to the response of a famous Islamic jurist to a question which has been asked as following: «Who is the supervisor (protector) of a child who hasn't become mentally mature after the majority and needs supervision? It has been said: «His supervision is related to his juridical guardian and it is different from custody right which is proved for one of the parents before maturity (Emami, 2001, p.187). Therefore, since the father has control on financial affairs of foolish one, in the event of committing fault in this regard and occurrence of loss by harmful act of foolish one, not only foolish one is responsible by referring to the articles 1215 and 1216 of Civil Code, the supervisor of foolish one (the father) is also responsible for injured party under the article 7 of Civil Responsibility Law. Of course, the responsibility of supervisor in financial affairs for harmed person is related to the case where the contracting party is ignorant of the incapacity of foolish one. Thus, in the cases of knowing this issue, responsibility is found neither for foolish one nor his/her supervisor. In this case, the owner has dominated foolish one on his property and this eliminates the respect of his property; therefore, it should be said that article 1215 of Civil Code relates to the existence of ignorance, because common sense is based on avoiding from trade with foolish one. In the United States, the parents are obliged to inform the others of dangerous states of their children; otherwise, they are responsible for their harmful acts (Zaker Hossein, 2011, p.8).

However, an objection which may be demonstrated from the view of some persons is this issue that the legislator hasn't mentioned the name of foolish person in the article 7 of Civil Responsibility Law and there is no other article about the responsibility of foolish one's supervisor. As we know, the article 7 of Civil Responsibility Law is related to the supervisors of minors and lunatics and it doesn't include the supervisor of foolish one. Additionally, the responsibility for acts of another person is contrary to the principle and it should be interpreted in a restrictive manner. Thus, the mentioned article may not be developed to the non-mentally mature persons (foolish) by broad interpretation. So, foolish ones always undertake personally the responsibility of their harmful acts. It may be said that the legislator stipulates in the article 1215 of Civil Code: «when a person gives the right of possessing a property to undiscerning minor or lunatic, minor or lunatic will not be responsible for impairing or wasting that property» and therein, lack of mentioning «foolish» beside minor and lunatic, has been deliberately. As the same way, in the article 7, lack of mentioning the name of «foolish» beside the name of minor or lunatic, has been intentional (Zaker Hossein, 2011, p.7). This is logical, because foolish one except in his/her financial affairs is accounted among others and acts according to the wise persons' method. Therefore, if any loss is exerted on another one by a foolish person, foolish one will be responsible (Shaygan, 1953, pp.57-58). But, if he/she has a supervisor (father) who has control on his/her financial affairs and the protector is careless in doing his duty, the protector will be responsible for the exerted harm since foolish one is incapable in financial affairs and needs to be protected. In the absence of explicit legal text, we can refer to the general legal rules and principles of Constitution to prove the responsibility of supervisor in the event of fault.

\section{A: The Cause Stronger Than Perpetrator}

In the cases where a foolish one harms others, like lunatic and minor, perpetrator is weak and the supervisor is considered as the stronger cause. In Islamic jurisprudence and law, wherever the cause is stronger, we know 
him/her responsible. So, about the loss arising from the act of foolish one, the supervisor may be known responsible; because the foolish one has been perpetrator in exerting the harm and since he/she is incapable in financial affairs, this is supervisor who is the stronger cause and if it wasn't his fault, no harmful act would occur.

\section{B: The Rule of Prohibition of Detriment}

Another known rule is the rule of prohibition of detriment (The rule of no damage) in which the holly prophet has negated the existence of any uncompensated damage. Whenever a foolish one exerts harm on another one, this harm should be prepared in a manner and this is the foolish one's supervisor that should prepare the harm, since his fault has caused the damage. The foolish one is incapable and the injured party is ignorant of incapacity. So, the only solution for avoiding from loss has been the supervisor prevention and the supervisor has failed to do so.

With regard to this issue that article 7 of Civil Responsibility Law has been adapted from Foreign law and in Switzerland's law according to the first clause of article 323 of law approved in 1907: «The manager of family is responsible for those losses that have been exerted by minors, lunatic and persons with weak wisdom under his custody; unless, it is proved that he has protected from them in a normal manner and according to the necessity of conditions» (Vaziri, 2001, p.389). So, it may be concluded that the purpose of Iran's legislator in the article 7 of Civil Responsibility Law hasn't been only minors and lunatics; rather it includes the persons with weak wisdom like foolish ones. Of course, foolish one has weak wisdom only in financial affairs.

\section{C: Principle 167 of the Constitution}

Principle 167 of the Iranian Constitution stipulates: «Judge is obliged to attempt for finding the sentence of each lawsuit in the codified laws and if he doesn't find, he should issue the sentence of each case by resorting to the Islamic valid sources and he may not prevent from investigation of lawsuit and issuance of sentence under the pretext of silence, defect, brevity or contradiction of codified laws». According to this principle, in the absence of explicit legal text, we should refer to the jurisprudence. In jurisprudence, the child when reaches to the majority and mental maturity age, exits from his/her parents' custody. Therefore, till a time that child is foolish and hasn't reached to the mentioned age, he/she is under his/her parents' custody. The parents, who are responsible for protection from him/her, are responsible for his/her harmful acts in the event of their fault.

\section{The Responsibility of Parents for Acts of Minor and Major Lunatic Children}

\subsection{Civil Responsibility of Parents for Acts of Lunatic Minor Child}

Lunatic like minors need to be taken care and protected, because for a physical or mental failure, they are affected by psychical disorder and have special tendency to harm others. Therefore, lunatics (insane persons) despite of their ages are in the same situation of minors and their harmful acts may cause the responsibility for supervisors in the event that their supervisor perpetrates fault in taking care of them (article 7 of Civil Responsibility Law). Lunatic (Insane) is a person who doesn't have wisdom power and is affected by mental power disorder. Diagnosis of lunacy isn't always an easy work and law can not present a certain criterion about it; therefore, its detection is in the charge of judge. Judge can use of the idea of expert and psychiatric; but anyway, making final decision about lunacy is with judge and obeying from the idea of expert and psychiatric isn't obligatory on him (Safai, 2007, p.86). In Iran and Switzerland's laws, the supervisor or manager of family is responsible both for the acts of minor and lunatic under his supervision. But, in France's law, the legislator is silent about lunatic and the responsibility of his/her supervisor will follow the general rules of responsibility. Thus, proving the fault of supervisor by the injured person is the condition of receiving the compensation. The concept of lunacy in the article 7 of Civil Responsibility Law is vaster than lunacy in penal concept (Shambayati, 1993, pp. 68-70) and includes all psychical disorders and mental retardations, since article 7 of Civil Responsibility Law has been adapted from Switzerland and France's laws and in Switzerland's law according to the first clause of article 323 of Civil Code approved in 1907, the manager of family is considered responsible for those losses which have been exerted by lunatics, minors and persons with weak wisdom under his custody, unless it is proved to the contrary; namely normal and reasonable protection by the protector is proved (Vaziri, 2001, p.389). This rule includes the persons with weak wisdom like those who have any kind of mental disorder.

Whatever is inferred from the ideas of Imamate jurists includes this issue that protection from lunatic before maturity and growth (mental maturity) is also like minors who are healthy. Some jurists in definition of custody have known it as guardianship on minor and lunatic. As Allameh Helli says: Custody is also proved on lunatic because he/she is as minor. According to the article 7 of Civil Responsibility Law, the parents have civil responsibility in the event of perpetration of harm by lunatic at any age under their supervision, because when 
supervisor fails to take care of him/her, he is situated in the position of the cause stronger than perpetrator and disconnects the casual relation between the act of lunatic and the suffered loss (Qasemzadeh, 1996, p.111).

\subsection{Civil Responsibility of Parents for Acts of Lunatic Major Child}

Now, a question is proposed, if child is lunatic at the time of reaching to the maturity and growth age and, in other words, his/her lunacy is connected to the time of minority, or lunacy occurs on him/her after maturity, or his/her foolishness is connected and continued after maturity or foolishness occurs on him/her after maturity, whether parents have the duty of protection (custody) on him/her or not? Some believe that if lunatic person reaches to the maturity age, he/she may not be left in the society without support and supervision. Due to the weakness of his/her mental power, he/she isn't able to take care of himself/herself and he/she may cause harm to himself/herself or another one. Therefore, the custody should be continued after maturity, whether the lunacy is connected or disconnected to the minority. About this issue that who undertakes the protection from lunatic after maturity, there are two ideas: One opinion is that protection from lunatic after maturity is undertaken by mother. Sheikh Toosi has expressed it and says: «In the event that a child reaches to the maturity age while he/she is lunatic or a wise child becomes lunatic, mother will be rightful for custody on him/her and having option in selecting between father and mother is lapsed after maturity; because he/she is as minor (Toosi, 1986, p.138). According to this idea, the protection from lunatic after maturity follows the criteria of protection from minor. The second opinion knows father as the protector of lunatic, as Allameh Helli says: The affairs of lunatic are undertaken by his/her father, although he/she has reached to the maturity age and, there is no difference between daughter and son in this field (Allameh Helli, 1991, p.44). As to the management of the financial affairs of lunatic, some Imamate jurists have differentiated between the lunacy connected to the minority and lunacy occurred after maturity and growth. In the event that his/her lunacy is connected to the minority, he is situated under the natural (legal) guardianship. But, whenever lack of growth (imbecility) or lunacy isn't connected to the minority time, he/she will not be under legal guardianship; because, natural guardianship ends with reaching to the maturity and growth age (Safai \& Emami, 2006, p.346).

Some of lawyers believe that taking care of lunatic person follows the criteria of protection from minor (Safai \& Emami, 2006, p.351); therefore, if incapable person doesn't have father, protection from him will be by mother. The Law Related to Give the Right of Protection from Minor or Incapable Children to Their Mothers approved in 1981 has followed this idea and has stipulated: «Custody on minor or incapable children whom father has suffered martyrdom or died, will be by their mother». In this article, the word of incapable which includes foolish and lunatic persons has been applied after minor; so, in addition to the lunatic one, it includes foolish one too. With regard to the idea of some jurists, lawyers and above article, protection from major lunatic follows the criteria and provisions of custody on the minors, especially, the mother will have priority in this regard after death of the father and this solution from their view, while honoring the mothers' personality, may be also justified by expedients of incapable person. Some others believe that responding to this question is negative theoretically (Katouzian, 1993, p.149); because mature foolish person doesn't need to the custody and his legal guardian will control his/her financial possessions. About lunatic person, the duty of parents should be known as a finished duty whether lunacy occurs after maturity or it is connected to the minority. They should protect from their child and it may not be claimed that they are responsible for lunacy of their child till the end of life. Perhaps the parents voluntarily accept the protection from their lunatic and physical disabled child and still undertake the protection from them due to affection and kindness on child but we can not force them to protect from these children. Such a duty may not be imposed on them without their consent (Moradzadeh, 2011, p.238). After maturity, the rules applicable to relatives' maintenance govern on financial needs of the child and protection from lunatic (custody) also follows the guardianship. The option of determining the executor for protecting and nurturing a child which his/her lunacy is connected to the minority, is a reason for this issue that protection from such a child is in the charge of legal guardian. Due to this, it was said that theoretically the custody on lunatic ends with reaching to the maturity. After maturity, father and fatherhood grandfather as legal guardian will undertake the same duty. Despite of this idea, Law of Giving the Right of Custody to the Mothers knows the mother as the protector of an incapable child that his/her father has died, whether lunacy and foolishness are connected to the childhood time or they occur after maturity (Katouzian, 1993, p.150). Under this opinion, this article in terms of respecting the mothers seems to be logical, but it isn't clear that death of father has what relation with protection from these incapable persons. Is father the protector of an incapable child who doesn't become mentally mature after majority or he/she is affected by lunacy in the minority time?

In this case, the custody on incapable follows the guardianship and law has known this guardianship for mother after death of the father. But, in the case of lunacy and foolishness occurred after maturity and growth, the assumption of continuation of guardianship isn't proposed and father plays no role in custody that may be 
substituted by mother after his death. So, the position of mother in this situation is a kind of independent custody which doesn't have any history in our law (Katouzian, 1993, p.150).

As conclusion of these two ideas, it may be said that according to the first idea, in the event of lunacy which is connected to the minority or occurs after maturity, the parents will have custody on the child and they will be entitled for protecting and taking care of him/her, but since no one has custody on foolish person and his/her incapacity is related to his/her financial affairs, in the event of connection of foolishness to the minority time or occurrence of foolishness after maturity, custody doesn't exist anymore and father or fatherhood grandfather or guardian should control on him/her financial affairs. Their failure to do so may result in their responsibility (article 7 of Civil Responsibility Law). In fact, their control is based on guardianship not custody. According to the second idea, custody will be ended with the maturity; so, there is no reason for custody any more, whether lunacy is continued after maturity or occurs after it. The mature foolish child doesn't need to be protected, whether his/her foolishness is connected to the minority or occurs later. Only father and fatherhood grandfather must control on him/her financial possessions and they must not permit him/her to harm another one; otherwise, they are responsible. About this issue that the legislator has given the custody of child to the parents, whether foolishness and lunacy are connected to the minority or occur later, it should be said that in the case of being connected, custody of incapable follows the guardianship rules and law has considered this guardianship for mother after death of father. In the event of occurrence after maturity, mother custody is a kind of independent custody, since the assumption of continuation of guardianship isn't proposed and father doesn't play any role in custody that after death, mother to be substituted instead of him. With regard to the Law of Giving the Right of Custody to the Mothers, the parents' custody is still being continued with lunacy and foolishness, whether lunacy and foolishness are connected to the minority time or they occur after maturity.

In France's law, based on broadly interpretation of the clause 4 of article 1384 of Civil Code, it may be said that whenever foolishness is connected to the minority time, guardianship will remain and thereupon, the parents' responsibility also remains. But, narrow interpretation of clause 4 of intended article indicates that the parents' responsibility will be negated after maturity of child, because otherwise, it is necessary that the parents to be responsible for compensating the losses arising from acts of their foolish children during their lifetime and this issue isn't compatible with judicial principles and it is contrary to the justice. In addition, according to the article 482 of France's Civil Responsibility Law, a minor whom incapacity has been removed, isn't under guardianship of the parents anymore and the parents have no responsibility for his/her harmful acts.

\section{Civil Responsibility of Parents for Acts of Physically Disabled Child}

Iran's Civil Code hasn't mentioned anything in relation to physically disabled person that is under protection. Article 823 of Germany's Civil Code, article 550 of Jordan's Civil Code and article 173 of Egypt's Civil Code have discussed about physically disabled child. According to these articles, a person who needs to be protected due to physical disability, should be supported and the assumption of fault has been stipulated against his/her legal or contractual protector. Likewise, protection of a person who has reached to the growth age (mental maturity) but has been affected by a disability which needs to be protected is undertaken by a person who controls on his/her personal affairs and the protector is responsible for harmful acts of the disabled person (Hejazi, 1954, p.521). It seems that these persons, by referring to the article 1 of Civil Responsibility Law and articles 328 and 331 of Civil Code, have civil responsibility for their harmful acts. With regard to the persons (parents) who undertake the duty of taking care of these children and in the event of their failure in protection of them, by invoking to the indirect causation rule (as the cause stronger than perpetrator) and as responsibility arising from another one's act (according to the interests that exist in this case and analogy of them), the supervisor of physically disabled person may be responsible for the exerted harms. In addition, article 7 of Civil Responsibility Law seems to be applicable to the physically disabled children. If physical disability is in the time of minority, he/she will be the subject of the article 7 of Civil Responsibility Law, but if the disability occurs after maturity or it is connected to the minority time, the same discussions which were expressed about lunatic or foolish major child, will be proposed. The Declaration on the Rights of Mentally Retarded Persons which was approved by United Nations in 1971, has mentioned in article 4 that the mental retarded person must live in his/her family or by the side of parents that have accepted him/her as child. The facilities and devices which are presented to the disabled person, should be planned in a manner that to be able to encourage him/her in reaching to a better life and as much as possible, these facilities should be provided in his/her family, the behavior of his/her family should be alike with other normal children of the same family and he/she should be helped for reaching to the independency in his/her personal affairs. It has been predicted in article 5 that if disabled child for some reasons doesn't have legal supervisor, for example, he/she has lost his/her parents or her/his parents have divorced from each other, protection from disabled person and his/her properties should be undertaken by a 
supervisor who is competent for this purpose (Tavassoli Naeeni \& Kaviar, 2008, p.63). In the Iranian law, it may be said that the parents as protector of their disabled children, will be liable for damages arising from acts of their children under the article 7 of Civil Responsibility Law (Jamshidi Rad et al, 2014, pp. 81-82).

\section{Conclusion}

According to the opinion of most jurists, the parents are obliged to protect from their children till the maturity and growth (mental maturity) time and in the event of failure to perform this duty properly, they will be responsible for exerted harms. Their responsibility about the acts of immature children (minors) is based on the idea of the cause stronger than perpetrator. As to the acts of mature and foolish children, in financial affairs where the father has guardianship, he is counted as the cause stronger than perpetrator and will be liable. In non-financial affairs, the parents' liability is justified in terms of principle 167 of Constitution by referring to the valid Islamic resources and the rule of prohibition of detriment. About the lunatic child, whether his/her lunacy is connected to the minority or not, the parents have duty to protect of him/her. With regard to the child who has physical disability, whether his disability is connected to the minority or not, the parents have duty in protecting and taking care of him/her and therefore, they will be liable for any loss which may be derived from their fault.

\section{References}

Ahmad ben Hamzeh, \& Shams al-Din Mohammad ben Abi al-Abbas. (1984). Nahayah al-Mohtaj Ela Sharh al-Menhaj (Vol. 7). Beirut, Dar al-Fekr.

Al-Āmeli, Zein al-Din ben Ali (Second Martyr). (1995). Masalek al-Afham Ela Tanqih Sharaye al-Islam (Vol. 8, 1st ed.). Volume 8, Institute of Islamic Knowledge.

Al-Āmeli, Zein al-Din ben Ali (Second Martyr). (2007). Al-Rozah al-Bahiyyah Fi Sharh al-Lomah al-Dameshqiyyah (Vol. 3, 5th ed.). Islamic Thought Assembly.

Allameh Helli, Hassan ben Yousof Motahhar. (1991). Tahrir al-Ahkam (Vol. 2). Marriage Book, Āl al-Bait Institute, Qom.

Bahjat (Foumani Gilani), Mohammad Taqi. (2005). Jame Al Masael (Vol. 4). The Author's office, Qom.

Dadmarzi, M., \& Kia, M. D. (2009). Obligations, Civil Liability (Vol. 2, 1st ed.). Publication of Qom University.

Doroudian, H. A. (1997, Spring). The Responsibility Arising From the Act of Persons That Are Under Another One's Protection. The Journal of Faculty of law and political sciences, (36).

Emami, H. (2011). Civil Law (Vol. 1\&5). Islamic publication.

Hejazi, Abd al-Hayy. (1954). General Theory of Obligations (Vol. 2). Nahzah Publication, Egypt.

Hossein, Z., \& Hadi, M. (2011). A Research on Civil Responsibility of Incapables and Their Supervisors. Journal of Trial, (9).

Jaziri, Abd al-Rahman. (1986). Al Feqh Ala al-Mazaheb al-Arbaeh (Vol. 4). Beirut, Dar al-Ehya al-Toras al-Arabi.

Katouzian, N. (2014). Civil Law; Family Law (Vol. 1\&2, 3rd ed.). Publication Company.

Macci al-Āmeli, Abi Abd Allah Jamal al-Din (First Martyr). (n.d.). Al-Lomah al-Dameshqiyyah. Marriage Book, Translated by Ali Shirvani, Dar al-Fekr, Qom.

Moqniyyah, M. J. (1995). Al-Feqh Ala al-Mazaheb al-Khamsah (3rd ed.). Imam Sadeq Institute, Tehran.

Moradzadeh, H. (2011). The Rights and Duties of Persons With Disability in Civil Responsibility System (1st ed.). City of Knowledge.

Motahhari, A. (1984). Mostanad Tahrir al-Vasilah. Marriage Book, Islamic Publication Institute, Qom.

Najafi, M. H. (1987). Jawaher al-Kalam (Vol. 31, 2nd ed.). Tehran, Al-Maktabah al-Islam.

Nazari, I. (2009). Civil Responsibility of Parents for Harmful Acts of Child. Neday -e- Sadeq Journal, (5).

Qasemzadeh, M. (1996). Civil Liability of Undiscerning Person. Judicial Law Views Quarterly, (2).

Rad, J., Sadeq, M., Kiai, M., \& Babakhani, E. (2014). Civil Responsibility of Parents for Disabled Children. Journal of Civil Law Knowledge, 2(6).

Safai, H. (2007). Persons and Properties (6th ed.). Mizan Publication.

Safai, H., \& Emami, A. (2006). A Concise of Family Law (10th ed.). Mizan Publication.

Safai, H., \& Qasemzadeh, M. (2007). Civil Law; Persons \& Persons Under Legal Incapacity (13th ed.). Samt 
Publication.

Safai, H., \& Rahimi, H. (2011). Civil Responsibility (2nd ed.). Samt Publication.

Shambayati, H. (1993). General Criminal Law (2nd ed.). Pazhang Publication.

Shaygan, A. (1953). Civil Law of Iran; Family (4th ed.).

Tabatabaee, M. A. (2000). Riaz al-Masael (1st ed.). Qom, Āl-al-Bait Institute.

Tavassoli Naeeni, M., \& Kaviar, M. H. (2008). A Reflection on the Rights of Disabled Persons From the Viewpoint of the Convention on the Rights of Persons with Disabilities and Other International Documents. Thoughts of Private Law Journal, 5(13).

Toosi, Abi Jafar Mohammad ben Hassan. (1986). Al-Mabsoot (Vol. 6). Maktabah al-Razaviyyah, Tehran.

Vaziri, M. (2001). Mutual Rights of Child and Guardian in Islam and Its Comparative Cases, MSc Thesis, Islamic Azad University, Sciences and Researches Branch.

\section{Copyrights}

Copyright for this article is retained by the author(s), with first publication rights granted to the journal.

This is an open-access article distributed under the terms and conditions of the Creative Commons Attribution license (http://creativecommons.org/licenses/by/4.0/). 